\title{
Not All Syrian Doctors Become Taxi Drivers: Stagnation and Continuity Among Highly Educated Syrians in Norway
}

\author{
Susanne Bygnes ${ }^{1}$ \\ Published online: 16 November 2019 \\ (C) The Author(s) 2019
}

\begin{abstract}
Many studies of forced migration have documented processes of deskilling and falls in status resulting from an inability to convert capital from one context to another. This article relies on qualitative interviews with highly educated individuals who arrived in Norway in the wake of the Syrian crisis. In the material, narratives of stagnation, loss and struggle against bureaucracy are highly salient and persist over time. I coin the term mobility dissonance to describe this post-migration stressor-the dissonance between physical mobility across borders and a sense of (not) going anywhere in life. By following some informants over time, this study indicates how classed resources can also represent an element of continuity through the critical life course events that forced migration entails. Descriptions of mobility dissonance are thus part of a more nuanced picture. While hopelessness and loss are very salient in the interviews, following informants over time provides lived examples of how classed resources represent an important form of continuity. Continuity refers to a counter-narrative to the riches-to-rags story often attached to resourceful forced migrants. I suggest future research to pay more attention to classed resources as a potential source of continuity through the migration process.
\end{abstract}

Keywords Bureaucracy $\cdot$ Class resources $\cdot$ Refugees $\cdot$ Highly skilled $\cdot$ Mobility dissonance

\section{Introduction}

The current article examines highly educated middle-class refugees' experiences. I investigate how a critical event — flight — influences individual biographies. In popular culture, the stories of people with higher education who are forced to flee are often framed within a riches-to-rags narrative. A resonating example is the doctor who works

Susanne Bygnes

Susanne.bygnes@uib.no

1 University of Bergen, PO BOX 7800, 5020 Bergen, Norway 
as a taxi driver in the country of residence. Such narratives find ample support in research on the post-migration trajectories of refugees. After resettlement, refugees are more likely than other migrants to be stuck in unemployment or jobs that do not match their qualifications (Conner 2010; Bakker et al. 2017). In-depth qualitative research has documented how highly educated individuals struggle with the downwards mobility and misrecognition that they experience after migration (Allsopp et al. 2015; Landolt and Thieme 2018; Markussen 2018). In addition, while pre-migration stressors are very common among people who flee war, recent studies have documented the particular effects of so-called post-migration stressors on refugees' lives after they seek asylum and gain residency (Bakker et al. 2014; Hainmueller et al. 2016; Miller et al. 2018). These include waiting for asylum decisions and can have severe negative effects on both mental health and socio-economic integration after residence (Bakker et al. 2014; Hainmueller et al. 2016). Recent qualitative research from the European context has reported that a substantial amount of the stress that asylum seekers and refugees experience relates to being subject to bureaucratic control both during and after the asylum-seeking phase (Chase 2013; Allsopp et al. 2015; Pearlman 2017; BuckenKnapp et al. 2018).

My analytical point of departure is a concept in the sociological literature on transitions from youth to adulthood, where critical moments are understood to be moments of particular biographical significance that can dramatically alter people's life trajectories and have important consequences for their lives and identities (Thomson et al. 2002). In this paper, I use the term 'critical event', which appears in the literature on social movements (Das 1995), to include reference to the large-scale critical event of the ongoing Syrian crisis.

While the paper departs from the analytical pre-supposition that forced migration represents a critical event in the life course, it also draws attention to the question of how classed resources may represent an element of continuity in the post-migration context. Cuzzocrea (2018) has recently argued that the focus on critical moments in the life course transitions literature has been foregrounded to such a degree that we need to ask whether we should pay more attention to continuities to understand how people project themselves into the future. Research findings that higher education and other class-based resources represent elements of continuity in individuals' lives after forced migration or that integration bureaucracy can facilitate rather than impede qualification processes are scarcer than findings supporting the riches-to-rags narrative. However, it has been documented that 'social and cultural resources' increase resilience against post-migration stressors (Hainmueller et al. 2016; Miller et al. 2018) and that the socalled refugee gap in employment narrows more quickly for those with higher education than for other refugees (Bakker et al. 2017; Hernes et al. 2019). Below, I both focus on post-migration stagnation and highlight the multifaceted nature of highly educated refugees' experiences.

In the current study, I focus on highly educated Syrians who arrived in Norway after the Syrian crisis erupted. The first round of interviews was conducted in 2016 and 2017. In 2019, I had the opportunity to conduct follow-up interviews with some of the informants. This created a wider perspective on the issue than the snapshot view provided by the one-off interviews. In the first round of interviews, informants largely focused on having to start life over again, bureaucratic slowness and a feeling of being stuck. However, following research participants up after 2 to 3 years revealed that 
educational and classed resources represented a source of continuity in their lives despite the unquestionable critical event in their life course. The second interview round allowed me to follow what had actually happened in their professional and private lives. Prompted by a pattern appearing in the empirical material over time, I adopt a 'dual focus' in this analysis that includes elements of both rupture and continuity.

\section{Syrians in Norway}

Before the 2011 uprisings in Syria and the subsequent war, the Syrian community in Norway accounted approximately for a mere 1000 individuals, but it now consists of more than 27,000 (Dzamarija 2018). Nine out of 10 Syrians have lived in Norway for less than 5 years. The group is relatively young and male dominated, about $25 \%$ arrived with college or university education (Dzamarija 2018). The vast majority of Syrians in Norway arrived as asylum seekers in the wake of the Syrian crisis and reached the country via the Mediterranean route passing through Turkey and Greece or the land route via the Balkans. However, during 2015, around 5500 asylum seekers from various countries crossed Norway's Arctic border with Russia. Norwegian authorities first refused to consider the asylum claims of applicants who entered via this route because they had visas to visit Russia. Individuals entering via the Arctic border therefore spent longer periods in asylum reception, and even asylum seekers from Syria experienced well-founded fears of deportation. After several rounds of negotiation, Russian authorities would not accept the return of the asylum seekers and Norway evaluated their claims in accordance with regular asylum procedures.

In Norway, the official 'integration phase' starts after a positive decision on an asylum claim and is followed by a two-year 'introductory programme'. Participants in the programme receive a monthly allowance for participating in Norwegian language training, schooling or practical work training intended to guide them into regular education or work (Djuve et al. 2017). During the introduction phase, the Norwegian Agency for Quality Assurance in Education evaluates the suitability of diplomas and previous education for the Norwegian system. A recent evaluation of the introductory programme concluded that while highly educated individuals were highly motivated during their participation in the programme, motivation was reduced among participants who felt a sense of uncertainty (Djuve et al. 2017). The evaluation also highlighted that implementation of the programme tended to vary according to street-level bureaucrats' values and personal attitudes towards it (Djuve et al. 2017: 306). Djuve and Kavli (2018) find that assumptions about refugees' motivations and path dependency within the introductory programme have resulted in a structure where good ideas have failed and bad ideas have tended to prevail, suggesting room for improvement in the practices of the integration bureaucracy.

In Norway, university education - including master's degrees - is free of charge and the state offers stipends and student loans to residents who qualify for higher education., Hernes et al. (2019) document that while highly educated individuals are more likely to be employed, curiously, men with university-level education are less likely to be employed than those with only secondary education. Despite a higher probability of participating in the labour market than the average refugee, higher 
education seems to produce a limited pay-off, at least in the short to medium run. While substantial state-funded programmes are in place to increase labour market participation, more use could be made of highly educated people's skills.

\section{Theoretical Conjectures}

This analysis draws on four theoretical concepts: critical events, post-migration stressors, mobility dissonance and continuity. In this section, I define and situate these key concepts in relation to each other. My analytical point of departure is the concept of a critical event. Here, I combine the usage of the concept of a critical moment from the sociological literature on transitions to adulthood with the concept of critical event from the social movement literature (Das 1995). The life course literature focuses on studying the impact of important or life-changing events or moments in people's lives that can dramatically alter their life trajectories and have important consequences for lives and identities (Thomson et al. 2002). The social movement literature uses critical events to analyse key macro events and their relationship with the inner life of individuals (Das 1995). Here I understand flight to be the key critical event. While any migration scholar is acutely aware that migration is a process and not an event, I still choose to zoom out and conceptualize the string of events entailed in leaving Syria and reaching Norway, as this critical event has important consequences for lives and identities. What happened before, during and after the flight, varies tremendously, but in all cases, daily lives and imagined futures lives were interrupted and then resumed in a radically different context. This interruption defines the critical event in the cases studied here. I respond to Holland and Thomson's (2009) suggestion that studying such critical life events can generate knowledge about the influence of social structures on individual biographies.

The next key concept used is post-migration stressors, an established concept from the field of disaster psychiatry (Norris et al. 2011; Li et al. 2016). This term denotes objectively stressful elements that occur after the critical event. Post-migration stressors are factors that have the potential to diminish the psychological well-being and economic integration of an individual. While resources such as family support, education and financial security promote well-being, post-migration stressors that diminish well-being include financial difficulties, unemployment, poor language skills and failure to recognize qualifications in the country of resettlement ( $\mathrm{Li}$ et al. 2016). I extend the focus on post-migration stressors from crisis psychiatry, and focus particularly on labour market trajectories and bureaucracy in the receiving context. Several large-scale quantitative studies have investigated the impact of factors such as separation from family and waiting time in asylum reception (Hainmueller et al. 2016; Miller et al. 2018). For example, Bakker and colleagues' study from the Netherlands (Bakker et al. 2014) finds that both length of stay in asylum reception and type of residency permits issued to refugees could have negative impacts on respondents' mental health and economic integration. Recent qualitative research has reported substantial stress related to dealing with and waiting for bureaucratic decisions (Chase 2013; Allsopp et al. 2015; Pearlman 2017; Bucken-Knapp et al. 2018). For example, Pearlman reports that a main concern of recently arrived Syrians in Germany was 'the overwhelming presence of the state bureaucracy' (2017: 314). Based on the analysis of the empirical 
material, I draw on a series of key stressors that informants describe as important to their post-migration experience and coin the term mobility dissonance.

The launch of the mobility dissonance concept draws theoretically on Hage's (2009) work on existential mobility, which describes the existential importance of maintaining a sense of moving forward in life. In his work on waiting, Hage (2009) suggests that potential migrants use migration as a launching pad for their existential mobility by 'looking for a space and a life where they feel they are going somewhere as opposed to nowhere, or at least where the quality of their going-ness is better than the space they leave behind' (2009: 98). Here, I introduce the concept of mobility dissonance to label the disjunction between the ability to move across borders and high expectations about the future on the one hand and the stagnation experienced after arrival. This concept is also inspired by ideas of the suffering of the immigrant depicted in Abdelmalek Sayad's (2004) classic work. However, unlike previous work on unmet expectations after emigration, I use the concept of mobility dissonance to describe the experiences recounted by young, highly educated Syrians who expected a middle-class life before fleeing Syria.

Finally, while mobility dissonance can be defined as a subjective sense of being unable to move forward in life, the final and fourth concept - continuity - refers to the opposite perception and actual progress in life. The label 'continuity' emerged from analytical work and is theoretically inspired by Cuzzocrea's (2018) call for analyses of young people's projection into the future to pay attention to continuities rather than focusing only on critical moments or rupture. I build on this idea to analyse actual future developments in the lives of the interlocutors in this project and highlight how classed resources play into these continuities. Although capital (and status) is often difficult to convert between contexts (Nieswand 2014; Rye 2019), I refer to it as an asset with the potential to create continuity between lives before and after migration.

\section{Data and Analysis}

I base the current analysis on qualitative interviews and follow-up interviews with recently arrived Syrians in Norway. In 2016 and 2017, together with an Arabicspeaking research assistant, I conducted open-ended, 1-2-h interviews with 26 individuals - 22 men and four women - between 18 and 35 years of age, mostly originating from Syria's largest cities. I interviewed eight of the informants again in 2019. All but one of the 26 interviewees either were planning to attend or were attending university, or they had already completed university-level education before coming to Norway in fields ranging from law and philology to engineering and medical sciences. The Arabic-speaking male research assistant with a Syrian background recruited interviewees by approaching potential participants in libraries, public squares, shopping malls and asylum reception facilities. I recruited informants through social media networks such as Refugees Welcome and in public meetings. Finally, four informants were recruited using the snowball method with the help of a key informant.

In the first interview round, most interviews were conducted individually but some participants were interviewed in pairs, and on two occasions, three individuals who knew each other well were interviewed together. A few interviews were conducted by the research assistant in Arabic. Other interviews were conducted with the research 
assistant present as an interpreter. More than half the interviews in the first round were conducted in English by the middle-aged, female Norwegian researcher. In the followup phase, all informants were interviewed individually - one in English and the rest in fluent Norwegian.

During the first round of interviews, I made the decision only to save contact data for the 14 informants who had already received their residency permits. This was to protect the privacy of asylum seekers in a particularly vulnerable position. Among the 14 individuals asked to participate in the follow-up phase of the study, eight agreed or had the opportunity to be reinterviewed. In 2019, I conducted 1-2-h follow-up interviews with these eight informants. All interviews were fully transcribed. There are minor differences in the profiles of the individuals I followed up compared with the initial group. As mentioned above, they had received residency permits when I first talked to them and were slightly older (22-35 years) and thus slightly more established in terms of educational tracks and careers than the individuals who only participated in 2016/2017. The types of backgrounds and educational profiles were very similar in both rounds. The first interview guide featured open questions about their lives before leaving Syria, their flight and their lives after arrival, important events and challenges, victories and future prospects. The second interview guide also featured open questions about where informants were in their lives right now, both professionally and personally. I invited them to tell me about their lives since we last spoke, plans that were realized or interrupted, their hopes, disappointments, feelings of belonging and plans for the future.

My analytical starting point for this paper was a question derived from the transitions to adulthood literature (Thomson et al. 2002): how does the critical event of fleeing Syria and coming to Norway influence individual biographies? I first coded the transcripts from the first interview round using an inductive, thematic analysis strategy (Braun and Clarke 2006). Frequently reoccurring themes foregrounded by the research participants and coded in the first round included continued life, hope, asylum, bureaucracy, waiting, frustration, slowness, lack of time, disappointment, starting again, papers, school, adulthood and wanting to work. I then proceeded to take the patterns in the surface meanings of the data to the next analytical level, creating overarching, theoretically informed categories related to literature on post-migration stressors, aspirations, expectations, temporality and stagnation. From these theoretical categories, I developed the first analytical category of mobility dissonance. After the first rounds of analysis of all the material, I selected four narratives to provide a detailed account of an important tendency in the material: an observed disconnect between geographic mobility and the feeling of not moving forward in the life trajectory, mainly attributed to the slowness of bureaucratic procedures.

Time became a central analytical element, but it was also an important part of the research design as the 2-3 years that passed between meeting the informants for the first and second interviews showed how both objective circumstances and people's frames of mind had changed. The eight interviews from round two were analysed in a new round of thematic analysis, and a new layer of analytical perspectives about continuity was added to perspectives about stagnation. When I sat down with people again after 2 years, they were able to tell their story from a different perspective. This final round contributed to the study by enabling an investigation of the role of passing time in people's lives, through changing circumstances and frames of mind. This served to expand the snapshot perspective that a single qualitative interview provides of a person's life. After the second round of analysis of the material, I decided to focus on 
three narratives and added an analysis of another central tendency in the material: an observed development over the course of 2-3 years indicating that they had made substantial progress towards regaining the middle-class existence that had seemed lost. I went back to the theory on transitions and drew on the concept of continuity (Cuzzocrea 2018). The selected cases were intended to highlight both important themes and central variations in the material. Their cases reflect different ages, genders and educational profiles, different routes into Norway and different experiences of Norwegian bureaucracy and different periods and types of education.

\section{Altered Life Trajectories in the Wake of the Crisis: Three Biographies}

\section{Mohammad}

Mohammad was in his early thirties when I first interviewed him in a café in a mediumsized Norwegian town. As a young man, Mohammad had decided to become a doctor and went abroad for several years to study. After he had finished his medical studies, war broke out in Syria. The situation left him with few opportunities to practise and no possibility of continuing in the specialization he needed to complete his degree. Therefore, he left Syria again after obtaining a temporary job as a doctor in another Middle Eastern country. Subsequently, he lost his job when he was unable to renew his visa because of the political situation in Syria, and he began seeking opportunities to go to Europe. After trying several other avenues, his last resort was to seek asylum in Europe. He had a family member and a friend in Norway at the time. He chose not to contact them before coming but did so after some time in asylum reception.

Mohammad describes crossing the Russian-Norwegian border in the Arctic in 2015, hoping to build a new life. Recalling the day he entered Norwegian territory, he provided a vivid recollection of his own sense of 'going somewhere' when he was standing at the border, imagining his future and the life before him:

At the border I waited for three hours and then the Norwegians said, 'you're welcome'. It was easy. I was shocked. At that time, you know, I thought heaven's doors were opening for me. Future, life, I am now in Europe.

According to his recollection, Mohammad imagined Norway to be a European 'space' that would enable him to 'go somewhere' in life. As noted above, many of the individuals arriving via the 'Arctic route' that year experienced long waits and a well-founded fear of deportation. Mohammad had to wait for 2 years, sometimes walking the streets of a northern Norwegian town at night during the long winter because he had heard the police came to deport people at night. After 2 years, he finally received his residency permit. However, after having reached the territory where he imagined his future would unfold, Europa, and finally having his asylum application granted, Mohammad no longer had a sense of going somewhere while sitting in the crowded café where I interviewed him:

I have lost everything. I have lost a lot of money and I have lost the girl I love. And you put me in waiting, a long time waiting. I even lost my ambition; I lost 
my motivation; I lost my everything. You made me a bad person, you know. And they told me, 'oh, you've got a chance to start a new life'. I told them no, I lost everything. [...] Some people, they told me two years is good; it is normal. I told them, 'no, not normal'. You can build a nation, you can build a country in two years. You know, all my friends got married and now they have two sons - my friends in other places. They finished their master's degrees.

Although he finally received a permit to stay in Norway, his case pinpoints with particular clarity the dissonance described between 'going somewhere' in terms of reaching a place and eventually being granted the right to stay there on the one hand while having a sense of going somewhere in life on the other (Hage 2009). Mohammad describes a strengthened sense of going somewhere by reaching potentially promising territory, yet being 'put in waiting' had undermined his sense of going somewhere in life. His laments echo a classic trope in the migration literature that highlights the suffering of the immigrant by documenting reactions to broken expectations and the shock of a new reality far from the imagined future (Sayad 2004). Inspired by the work of Hage (2009) and Sayad (2004), Mohammad's case provides the first example of what I conceptualize here as mobility dissonance.

At the time of the first interview ( 2017), Mohammad insisted that he wanted to return to Syria even if he had to 'live in a tent'. However, when I interviewed him again in 2019, his frame of mind had changed. In the second interview, he also focused largely on bureaucratic obstacles, this time evolving around the paperwork for his medical licence to be accepted to enter a requalification programme for people with degrees from outside of Norway. He said, I am 'just doing applications, paying the fees, waiting, making a lot of phone calls, eh, complaining about decisions, some decisions, and here we are, nothing. [...] Yeah. I'm really frustrated'.

However, 1 and a half years after receiving his residency permit, his sense of stagnation and uncertainty about the future seemed less and he appeared calmer and more hopeful. As suggested in the quote above, Mohammad was still clearly frustrated by bureaucracy. Nevertheless, he seemed to have found a way to manoeuvre within it by actively seeking out alternative opportunities for himself and making contact with other doctors who had made it:

[In addition] I contacted the [name of Norwegian University] to enrol, for example for a master's degree. It is better not to wait for anything, but just do something useful [...] by studying molecular medicine [...]. It's like a new field in medicine.

$[\ldots]$

I have contacted many migrants, Arab migrants, (who) came to Norway a long time ago, from places like Iraq. One of them was a doctor and he told me that he struggled. He struggled for maybe five years. And he didn't receive permission. So, there he told me that there are alternative ways. I asked him 'what are they?' He said he went to Sweden and he got authorization to practise in Sweden, which [is easier], much easier than in Norway. Then ((short laugh)) he came back to Norway.

Mohammad himself suggests that part of his 'problem' can be explained by his high expectations, but that he has adapted, not so much by lowering his expectations, but by accepting that things will take a much longer time than expected. 
Mohammad: The problem is not special for me. But my, my, perception, my viewpoints, my expectation, once I feel it, for example, I expect to do something and I.., I couldn't, so I can't. That frustrates me, disappoints me, depresses me and confuses me. So, that's the problem.

Interviewer: So, would you say that you arrived with high expectations?

Mohammad: Eh. Let's say yes, with great expectations. But with the new bureaucracy with a lot of requirements that I couldn't fulfil now, so yeah... disappointed, and a little bit depressed, not [clinically] depressed. [...] in my subconscious I said OK, maybe five to ten years, after five or ten years then maybe I will [have a good life]. So there is no, you know, rush. Yeah. Let it be.

While Mohammad had seemed overwhelmed with mobility dissonance in the interview nearly 2 years before, he tellingly ended the second interview with the words 'let it be', saying that he had accepted his situation and that things would take time, but he had regained belief that he might get his life back. Discouraged by the long and winding road of bureaucratic processes, he seems to have found a way to adjust his life pace and expectations to the bureaucratic pace and to maintain hope by foregrounding stories about doctors who made it and accepting that things take time.

\section{Sali}

Sali was in her early twenties when I first interviewed her. For her, leaving the Damascus suburb where she lived with her family to go to a cousin's wedding seemed undramatic at the time. Sali left Syria carrying only 'holiday stuff' such as dresses for the wedding. However, during her stay, the area where her family lived was bombed several times and her mother returned to fetch papers and other important objects. Sali was exhausted after finishing a key milestone-her final exams - and she was preparing for adulthood. However, the widespread critical events that followed were an important rupture in her life trajectory (Holland and Thomson 2009). From 1 week to the very next, she went from graduate and holidaymaker to refugee in a neighbouring country. After living in the Middle East for a while, starting university there and working for an NGO, Sali hoped to join members of her family who were in Norway. She arrived by plane in 2015 and proceeded to seek asylum. In contrast to Mohammad, Sali did not describe a sense of mobility dissonance when she discussed her time in asylum reception. She seems to have maintained a feeling of going forward in life during the asylum process and enjoyed her stay in the reception facility, which lasted for 4 months.

Sali had had the opportunity to return to her university track during her time in a neighbouring country. However, at the time of the first interview, she had already spent several years unable to re-enter university in Norway and was becoming very frustrated. As her interview shows, after 2 years she was still waiting to 'start her life' again. She had to wait for the approval of her university credentials and was extremely disappointed to hear that she had to return to upper secondary school to prepare for a Norwegian version of the final exam she had taken prior to leaving Syria:

[I]t is so difficult to start again and again and again. Because even though in Norway I am young, some people start studying when they are my age; they have done other things in their lives[...] You have to go back to a place that you 
already finished; your life stops, and you have to start again. It is difficult. [...] I got depressed I think. It was very stressful. I got depressed and I stopped studying. I lost my motivation to learn the language.

Even though Sali enjoyed her time at the asylum reception centre and has a network of family and friends in Norway, she describes the period after receiving a 'positive decision' on her asylum application as very hard. Her case provides an example of how the experience of slow procedures and bureaucratic decisions contribute to a sense of going backwards on one's life trajectory. The mobility dissonance caused in this phase of her new life in Norway caused depression and loss of hope and reduced her motivation to continue her studies and to learn the language. Sali attributes her inability to feel that she is 'going somewhere in life' to both major critical events and unexpected bureaucratic control of her life trajectory. Through the negative decisions about her applications to continue university, she found that capital is not always convertible from one context to another (Nieswand 2014; Rye 2019). However, this does not mean that her educational background and classed resources were useless to her in the new context.

When we interviewed her again in 2019 , she spoke fluent Norwegian and was finally able restart her university education and continue where she had left off in Syria. Thinking about the 4 years spent at school in Norway before she could continue her life made her somewhat angry:

I am still a bit angry, actually. A bit. Because it took more time than it should have taken. There is nothing positive about having to take upper secondary school again, spending two years doing that. The only positive thing about it was that I was able to develop my Norwegian language skills. [...] Doing school again here is nothing. But there are some small things that made me proud, like passing [an advanced Norwegian language test]. Because I know that was a real challenge. [...] passing that that made me very proud and happy. [...] Also, when I was able to start doing some subjects at university... during these three or four years my goal has been to start university, so when I started this spring, I felt very happy.

She is now starting the bachelor's degree she wanted and plans to continue her university studies to obtain a master's degree but is also considering doing a $\mathrm{PhD}$. At 25 , she is looking forward to 'starting a stable life' as a university student where she can concentrate on other things than pronouncing new and difficult sounds in a new language: 'Now I do not want to start again. [...] I do not want to leave or live somewhere else. I like travelling and seeing new places, but I cannot imagine moving to another country'. While mobility dissonance has been an intense post-migration stressor, her resources and the educational possibilities at hand represent a realistic opportunity to continue the middle-class life she imagined before the critical event in her biography.

\section{Faisal}

Faisal was in his late twenties when I interviewed him in 2017. Coming from a family of doctors, Faisal had finished his dental degree and started practising one year before the war broke out in Syria. He managed to continue training in his specialization but had to break it off after a few years because of the war. After a hospital where he 
worked as a volunteer was bombed, he decided to leave for Europe. After a dramatic flight via the Mediterranean, he landed at a Norwegian airport in late 2014. Faisal waited 4 months to receive a positive decision on his asylum application in Norway. He learned that the processing of his asylum application had been delayed owing to the case officer being on holiday. 'It was the first time I really understood what that phrase ting tar tid [...] means, I just wanted my life to... that something would happen, to move forward'. Faisal indicates that even though his wait was relatively short, the meaning of having his life ruled by bureaucracy dawned on him once he understood the Norwegian saying 'things take time'. He contrasts the assumption of unavoidable waiting and the appeal for patience captured in that saying with his strong wish for life to 'move forward' and describes the period governed by the Norwegian Directorate of Immigration as 'the worst days of my life in Norway'.

Losing time is a key theme in Faisal's interview. He exemplifies discords in tempo between the life he had hoped for and the life he lives by contrasting bureaucrats and teachers' comments about 'having time' with his own sense of urgency. 'Also, in the introduction programme and in the language school they asked me: "why do you nag so much? You have time". I didn't think I had time'. From the perspective of teachers and bureaucrats, Faisal has time. However, his own perception is one of losing time and losing the future he envisioned. As in Mohammad's case, Faisal highlights a sense of dissonance between what he had expected of his life after making it to Norway and what he experienced.

Like Mohammad, Faisal continues by describing a range of strategies to re-enter the adult life he had established before leaving Syria. His strategies are all closely connected to his class-based resources: language skills, higher education, eloquence and ability to manoeuvre his way through a complicated bureaucratic system. When I interviewed him in 2017, Faisal already spoke fluent Norwegian and English and he had recently been admitted to an extremely competitive qualification programme for dentists at a university. However, he had found the entry process to be governed by such impenetrable bureaucracy that he began to make a manual for people who came after him to make the process less Kafkaesque. Like several other informants, Faisal points out that the bureaucracies connected with integration and higher education respectively do not seem to communicate with each other at all.

Faisal aspires to be 'independent' and to have a 'normal' future. As examples of the 'normal' life he hopes for, he refers to friends who have managed to re-enter adult life after seeking asylum. 'Several of my friends who came to Norway are civil engineers, and they have permanent positions now. Some of them bought houses and... they are well'. He juxtaposes his references to middle-class adult life with his own feeling of being stuck: 'I am almost 30 years old now and it is time to build a life. Enough of being a student $[\ldots]$ and living in a student house. Enough insecurity'. Interestingly, when Faisal talks about the possibility of being 'sent back to Syria', it is this prolonged suspense that he seems most worried about: 'If they decide that Syria is a safe country now, and they can, then they will send us back and it will be four years. I threw away four years of my life in Norway, without having done anything'.

In 2018, we learned that after living in Norway for 4 years, Faisal had taken a large step towards the future he envisioned when he obtained a licence to practise. Thus, as shown in previous research (Bakker et al. 2014; Djuve et al. 2017), cases like Faisal's show how higher education and a middle-class background are resources on which research participants often do capitalize after arrival. When I interviewed Faisal again in April 2019, he 
had moved to another town and started up his own practice. He had sent many job applications and struggled to enter the labour market after he received his authorization and decided the solution was to start working with Arabic-speaking patients. We talked about his frame of mind now compared with that when he first arrived in 2014 and when I interviewed him in my office in 2017. Faisal summarized his present situation as follows:

Each day I get more clients [...] I think it has been a great success. I am really proud. [...]. I will soon buy my own clinic, that is my future [...]. So, for now, when we do this interview, I am thinking that my future will be about business.

At this point, Faisal reported earning good money; he lived in a large apartment in the city centre, enjoyed an active social life and frequent holidays in Europe. The 2 years that had passed since I interviewed him the first time had changed both his situation and outlook radically. He was no longer focused on bureaucratic processes. His classed resources, intense personal effort, the passing of time and the requalification programme for dentists at university had resulted in Faisal's readmission into a middle-class lifestyle. While his life had been in danger several times before he arrived in Norway, and his first few years here were hampered by a sense of frustration and loss, his case is one of several clear examples in the interview material of how classed resources include components of both crisis and continuity and of losing and regaining footholds.

\section{Conclusion}

This paper began with the theoretical assumption that studying critical events can generate knowledge about the influence of social structures on individual biographies (Holland and Thomson 2009). Based on this qualitative study of highly skilled Syrians in Norway, my contributions to the literature are twofold. First, I extend the literature on post-migration stressors, existential mobility and unmet expectations after migration and introduce the concept of mobility dissonance. This is used to unpack the sense of overwhelming stagnation and descriptions of going nowhere in life that the interlocutors describe after they manage to reach safe territory. While it is important that previous studies (for example, Hague 2009; Allsopp et al. 2015) have thematized immobility and waiting, the highly educated individuals studied here were physically mobile and most Syrians who arrived in Norway in this period had their asylum applications granted without protracted waiting. Although the informants were physically mobile and most were granted permits to stay, the concept of mobility dissonance refers to experiences with Norwegian bureaucratic processes, which seem endless and poorly organized, but also to an existential feeling of losing the best years of their lives and their expectations of what the future will bring. The concept thus describes the disjunction between the ability to move across borders with high expectations about the future on the one hand and the stagnation experienced after arrival. Similar to the post-migration stressors described in the literature on disaster psychiatry, mobility dissonance has the potential to diminish psychological well-being and the economic integration of individuals ( $\mathrm{Li}$ et al. 2016).

While paying close attention to this objectively observable and subjective sense of failing to move forward professionally or personally, I drew on follow-up interviews and continued to analyse some of the objective aspects and subjective considerations related to moving 
forward in life. The second round of analysis revealed an important development. Over the course of 2-3 years, informants in practice had taken substantial strides towards regaining their middle-class existence. Their situations during the final interview revealed that seven informants spoke Norwegian fluently, three owned houses and five owned cars. Two informants had obtained permanent jobs within their profession, three had divided their time between low- or medium-skilled jobs and university, two were full-time university students and one was still in the introduction programme working to continue his studies for the medical profession.

Thus, based on the analysis of the follow-up interviews, my second contribution to the literature was conceptualizing what I suggest to be a counter-narrative to the richesto-rags story often attached to resourceful forced migrants. As my interlocutors discovered, not all Syrian doctors become taxi drivers in the post-migration context. I argue that continuity can add an important layer to studies of forced migration. The term is extended from Cuzzocrea's (2018) call to examine not only critical moments of people's life trajectories, but also elements of continuity. I expand on her suggestion and show how classed resources such as higher education appear to represent continuity between the pre- and post-migration lives of highly skilled and resourceful individuals like those interviewed for this study. Previous research has documented that 'social and cultural resources' increase resilience against post-migration stressors (Bakker et al. 2014; Hainmueller et al. 2016; Miller et al. 2018) and that refugees with higher education fare better in the labour market than other refugees (Bakker et al. 2017). However, studies focusing on how classed resources remain important assets in the post-migration context are lacking. I do not attempt to mitigate the real hardship of downward social mobilization or sense of mobility dissonance experienced in postmigration contexts, but rather suggest future research to acknowledge the underresearched counter-narratives that arise in addition to riches-to-rags narratives.

Acknowledgements I am deeply grateful to the research participants contributing to this study. I am indebted to Helga Eggebø for her careful reading of previous versions of the manuscript. I would also like to thank the IMEX advisory board members and participants, participants 'Temporalities of Migration and Integration' panel at the 2018 IMISCOE-conference and the participants at 'Forced Migration, Exclusion and Social Class' workshop at the Max Plank Institute for valuable comments.

Funding Information This work was supported by The Research Council of Norway under Grant number 262987.

Compliance with Ethical Standards No conflict of interest to report from this study.

\section{References}

Allsopp, J., Chase, E., \& Mitchell, M. (2015). The tactics of time and status: young people's experiences of building futures while subject to immigration control in Britain. Journal of Refugee Studies, 28(2), 163182. https://doi.org/10.1093/jrs/feu031.

Bakker, L., Dagevos, J., \& Engbersen, G. (2014). The importance of resources and security in the socioeconomic integration of refugees. A study on the impact of length of stay in asylum accommodation and residence status on socio-economic integration for the four largest refugee groups in the Netherlands. International Migration \& Integration, 15(3), 431-448. https://doi.org/10.1007/s12134-013-0296-2. 
Bakker, L., Dagevos, J., \& Engbersen, G. (2017). Explaining the refugee gap: a longitudinal study on labour market participation of refugees in the Netherlands. Journal of Ethnic and Migration Studies, 43(11), 1775-1791. https://doi.org/10.1080/1369183X.2016.1251835.

Braun, V., \& Clarke, V. (2006). Using thematic analysis in psychology. Qualitative Research in Psychology, 3(2), 77-101. https://doi.org/10.1191/1478088706qp063oa.

Bucken-Knapp, G., Fakih, Z., \& Spehar, A. (2018). Talking about integration: the voices of Syrian refugees taking part in introduction programmes for integration into Swedish society. International Migration, 57(2), 221-234. https://doi.org/10.1111/imig.12440.

Chase, E. (2013). Security and subjective well-being: the experiences of unaccompanied young people seeking asylum in the UK. Sociology of Health and Illness, 35(6), 858-872. https://doi.org/10.1111 j.1467-9566.2012.01541.x.

Conner, P. (2010). Explaining the refugee gap: economic outcomes of refugee versus other immigrants. Journal of Refugee Studies, 23(3), 377-397. https://doi.org/10.1093/jrs/feq025.

Cuzzocrea, V. (2018). A possibility to square the circle? Youth uncertainty and the imagination of late adulthood. Sociological Research Online, 23(3), 671-686. https://doi.org/10.1177/1360780418775123.

Das, V. (1995). Critical events: an anthropological perspective on contemporary India. New Delhi: Oxford University Press.

Djuve, A. B., \& Kavli, H. C. (2018). Refugee integration policy the Norwegian way - why good ideas fail and bad ideas prevail. Transfer-European Review of Labour and Research, 25(1), 25-42. https://doi. org/10.1177/2F1024258918807135.

Djuve, A. B., Kavli, H. C., Sterri, E. B., \& Bråten, B. (2017). Introduksjonsprogram og norskopplaering. Hva virker for hvem? [Introductory Programme and Norwegian Language Training. What Works - For Whom?] Fafo Rapport 2017:31. Oslo: Fafo.

Dzamarija, M., (ed.). (2018). Innvandrere og norskfødte med innvandrerforeldre fra Syria [Immigrants and Norwegian-born with immigrant parents from Syria]. Rapport 24/2018. Oslo: Statistics Norway.

Hage, G. (Ed.). (2009). Waiting. Carlton: Melbourne University Publishing.

Hainmueller, J., Hangarter, D., \& Lawrence, D. (2016). When lives are put on hold: lengthy asylum processes decrease employment among refugees. Science Advances, 2(8), e1600432. https://doi.org/10.1126/sciadv.1600432.

Hernes V., Arendt, J. N., Joona, P. A., \& Tronstad, K. R. (2019). Nordic integration and settlement policies for refugees: a comparative analysis of labour market integration outcomes. Nordic Council of Ministers.

Holland, J., \& Thomson, R. (2009). Gaining perspective on choice and faith: revisiting critical moments. European Societies, 11(3), 451-469. https://doi.org/10.1080/14616690902764799.

Landolt, S., \& Thieme, S. (2018). Highly skilled migrants entering the labour market: experiences and strategies in the contested field of overqualification and skills mismatch. Geoforum, 90, 36-44. https://doi.org/10.1016/j.geoforum.2018.01.009.

Li, S. S., Liddel, B. J., \& Nickerson, A. (2016). The relationship between post-migration stress and psychological disorders in refugees and asylum seekers. Current Psychiatry Reports, 18(9), 82. https://doi.org/10.1007/s11920-016-0723-0.

Markussen, M. K. G. (2018). 'Nobody comes to Baba for advice': negotiating ageing masculinities in the Somali diaspora. Journal of Ethnic and Migration Studies. https://oi.org/10.1080/1369183X.2018.1496817.

Miller, A., Hess, J. M., Bybee, D., \& Goodkind, J. R. (2018). Understanding the mental health consequences of family separation for refugees: implications for policy and practice. American Journal of Orthopsychiatry, 88(1), 26-37.

Nieswand, B. (2014). The burgers' paradox: Migration and the transnationalization of social inequality in southern Ghana. Ethnography, 15(4), 403-425.

Norris, A., Arojan, K., \& Nickerson, D. (2011). Pre-migration persecution, post-migration stressors and resources, and post-migration mental health: a study of severely traumatized U.S. Arab immigrant women. Journal of American Psychiatric Nurses Association, 17(4), 283-296. https://doi.org/10.1177/1078390311408900.

Pearlman, W. (2017). Culture or bureaucracy? Challenges in Syrian refugees' initial settlement in Germany. Middle East Law and Governance, 9(3), 313-327. https://doi.org/10.1163/18763375-00903002.

Rye, J. F. (2019). Transnational spaces of class: international migrants' multilocal, inconsistent and instable class positions. Current Sociology, 67(1), 27-46.

Sayad, A. (2004). The suffering of the immigrant. Cambridge: Polity Press.

Thomson, R., Bell, R., Holland, J., Henderson, S., McGrellis, S., \& Sharpe, S. (2002). Critical moments: choice, change and opportunity in young peoples' narratives of transition. Sociology, 36(2), 335-354. https://doi.org/10.1177/0038038502036002006.

Publisher's Note Springer Nature remains neutral with regard to jurisdictional claims in published maps and institutional affiliations. 